\title{
PENERAPAN ASSESMEN PROYEK UNTUK MENINGKATKAN REPRESENTASI DAN MENGGURANGI KECEMASAN SISWA
}

\author{
Rasilah \\ STKIP NU Indramayu, Jalan Raya Kaplongan No. 28 Karangampel Indramayu 4528, \\ rasilah.pramuka@gmail.com
}

Diterima 18 Februari 2018, disetuji 2 Maret 2019, diterbitkan 30 April 2019

Pengutipan: Rasilah. (2019). Penerapan Assesmen Proyek Untuk Meningkatkan Representasi dan Menggurangi Kecemasan Siswa. Gema Wiralodra, Vol 10, No 1, Hal 115-129, April 2019

\begin{abstract}
ABSTRAK
Tujuan penelitian ini adalah untuk melihat mana yang lebih baik antara siswa yang memperoleh pembelajaran assesmen proyek dan siswa yang memperoleh pembelajaran konvensional serta korelasi antara kecemasan matematika dengan kemampuan representasi. Metode penelitian ini adalah penelitian Mix Method tipe Concurrent Embedded Model, merupakan metode yang mengkombinasikan penggunaan metode penelitian kuantitatif dan kualitatif secara simultan/bersama-sama (atau sebaliknya) tetapi bobodnya berbeda-bedaPopulasi dalam penelitian ini adalah seluruh siswa SMP Nu darul Maarif Indramayu mengambil dua sampel kelas VII secara acak.Instrumen yang digunakan adalah instrumen tes dan non-tes. Instrumen tes berupa tes kemampuan reprsntasi matematis, angket untuk mengetahui sikap siswa, observasi dan wawancara untuk mengetahui kekeliruan jawaban siswa. Berdasarkan hasil analisis data dan pengujian hipotesis, diperoleh kesimpulan bahwa : 1) terdapat perbedaan peningkatan kemampuan representasi matematis yang memperoleh pembelajaran assesmen proyek dan siswa yang memperoleh pembelajaran konvensional. 2) terdapat peningkatan kemampuan yang memperoleh pembelajaran assesmen proyek dan siswa yang memperoleh pembelajaran konvensional dilihat dari kemampuan awal matematika (tinggi, sedang, rendah). 3) terdapat hubungan antara kemampuan representasi dengan kecemasan matematika, Siswa yang menggunakan model pembelajaran assesmen proyek mengalami tingkat kecemasan sedang,dan pembelajaran konvensional mengalami tingkat kecemasan berat.
\end{abstract}

Kata Kunci: Pembelajaran Assesmen Proyek, Kemampuan representasi, Kecemasan Matematika.

\begin{abstract}
The purpose of this study is to see which is better between students who get project assessment learning and students who get conventional learning and the correlation between mathematical anxiety and representation ability. This research method is the Concurrent Embedded Model type Mix Method research, which is a method that combines the use of quantitative and qualitative research methods simultaneously / together (or vice versa) but the bobods vary. The population in this study is all junior high school students of $\mathrm{Nu}$ darul Maarif Indramayu took two Class VII samples were randomly assigned. The instruments used were test and non-test instruments. Test instruments in the form of mathematical identification ability tests, questionnaires to determine student attitudes, observations and interviews to find out errors in student answers. Based on the results of data analysis and hypothesis testing, the conclusion is that: 1) there are differences in the increase in the ability of mathematical representation to obtain project assessment learning and students who obtain conventional learning. 2) there is an increase in the ability to get project assessment learning and students who get conventional learning are seen from the initial ability of mathematics (high, medium, low). 3) there is a relationship between the ability of representation with mathematical anxiety, students who use the project assessment learning model experience moderate levels of anxiety, and conventional learning experiences severe levels of anxiety.
\end{abstract}

Keywords: Project Assessment Learning, Representative Ability, Mathematical Anxiety. 


\section{PENDAHULUAN}

Mata pelajaran matematika merupakan pelajaran yang sangat diperlukan untuk melatih kompetensi siswa. Berdasarkan Peraturan Menteri Pendidikan Nasional No 22 tahun 2006 tentang Standar Isi, mata pelajaran matematika SMP/MTs bertujuan agar siswa memiliki kemampuan diantaranya: (1) Memahami konsep matematika, menjelaskan keterkaitan antar konsep dan mengaplikasikan konsep atau algoritma, secara luwes, akurat, efisien, dan tepat, dalam pemecahan masalah; (2) Menggunakan penalaran pada pola dan sifat, melakukan manipulasi matematika dalam membuat generalisasi, menyusun bukti, atau menjelaskan gagasan dan pernyataan matematika; (3) Memecahkan masalah yang meliputi kemampuan memahami masalah, merancang model matematika, menyelesaikan model dan menafsirkan solusi yang diperoleh; (4) Mengkomunikasikan gagasan dengan simbol, tabel, diagram, atau media lain untuk memperjelas keadaan atau masalah; (5) Memiliki sikap menghargai kegunaan matematika dalam kehidupan, yaitu memiliki rasa ingin tahu, perhatian, dan minat dalam mempelajari matematika, serta sikap ulet dan percaya diri dalam pemecahan masalah.

Namun demikian, berdasarkaan hasil penelitian Ismunandar (2016), hasil belajar siswa di salah satu sekolah tingkat SMA di kabupaten Indramayu, hasil belajar siswa mata pelajaran matematika walaupun sudah memenuhi KKM, hasil belajar siswa masih belum memuaskan. Hal ini selaras dengan studi pendahuluan yang dilakukan peneliti terhadap 30 siswa kelas IX.G dengan menguji cobakan satu soal berbentuk pemecahan masalah dengan materi bangun datar segi empat dan segi tiga, hasilnya adalah $80 \%$ siswa belum mampu menyelesaikannya dengan baik. Mereka tidak mampu menjelaskan keterkaitan antar konsep dan mengaplikasikan konsep dalam pemecahan masalah, bahkan ada sebagian siswa yang lembar jawabannya belum diisi dengan alasan sulit. Hasil observasi dan wawancara dengan guru mata pelajaran matematika kelas delapan tahun pelajaran 2014/2015 diperoleh bahwa siswa kelas tujuh tahun pelajaran tersebut mengalami kesulitan dalam belajar matematika terutama pokok bahasan segitiga dan segi empat, siswa sangat lemah mengaitkan antar konsep seperti lupa konsep sudut, lupa konsep segitiga bahkan konsep pun banyak yang belum menguasai sehingga kemampuan pemecahan masalah masih rendah. Menurut analisis penulis, hal tersebut mungkin disebabkan oleh beberapa faktor, diantaranya : (1) siswa kita sudah terbiasa bertemu soal-soal rutin, sedangkan untuk soal yang sifatnya menguji kemampuan khusus matematis jarang diberikan, sehingga ketika siswa bertemu soal yang high order thinking, siswa kita kaget; (2) siswa kita kurang dibiasakan mengaitkan materi pembelajaran dengan materi yang telah diterima 
sebelumnya, antar konsep, bahkan kehidupan sehari-hari, serta (3) pembelajaran dikelas yang dominan menggunakan pembelajaran konvensional seperti menjelaskan judul materi, contoh soal kemudian latihan soal; (4) penilaian yang didominasi oleh hasil UTS dan UAS, kurang melibatkan penilaian proses. Berdasarkan identifikasi masalah di atas, peneliti berusaha untuk meningkatkan kemampuan representasi dan mengurangi kecemasan matematika siswa melalui penilaian proyek dan represntasi asesmen proyek. Berdasarkan uraian yang telah dijabarkan pada latar belakang masalah, maka penulis merumuskan masalah sebagai berikut :

1) Apakah Peningkatan kemampuan representasi siswa yang mendapatkan pembelajaran Assesment Proyek lebih baik dari pada siswa yang mendapatkan pembelajaran konvensional?

2) Apakah Peningkatan Kemampuan representasi siswa yang memperoleh Penerapan Assesmen Proyek lebih baik dibandingkan dengan siswa yang memperoleh pembelajaran konvensional, dilihat dari kemampuan awal matematika (tinggi, sedang, rendah)?

3) Apakah Terdapat hubungan antara kemampuan awal matematika (KAM) dengan Penerapan Asesmen proyek terhadap kemampuan representasi siswa.?

4) Apakah terdapat hubungan antara kemampuan representasi dengan kecemasan siswa?

5) Bagaimana sikap siswa terhadap pembelajaran matematika setelah melaksanakan pembelajaran assesmen proyek

\section{METODE PENELITIAN}

Penelitian ini menggunakan metode gabungan (mixed method) dengan Concurrent Embedded Model. Mixed method merupakan pendekatan dalam penelitian yang mengkombinasikan atau menghubungkan antara metode penelitian kuantitatif dan kualitatif, yang mencakup landasan filosofis, penggunaan pendekatan kuantitatif dan kualitatif, dan mengkombinasikan kedua pendekatan tersebut (Creswell, 2009). Selanjutnya, Mixed Method dengan Concurrent Embedded Model merupakan penelitian yang mengkombinasikan metode kuantitaitf dan kualitatif secara simultan atau bersamasama, tetapi bobot metodenya berbeda.

Pengukuran hasil belajar siswa secara kuantitatif dilakukan sebelum dan sesudah diberikan perlakuan melalui pemberian soal tes kemampuan pemecahan masalah dan kemampuan representasi . Selain pengaruh faktor pembelajaran, dalam penelitian ini dilibatkan pula pengaruh faktor tingkatan kemampuan siswa, yaitu akan dikaji interaksi siswa terhadap pembelajaran yang digunakan dengan memperhatikan kategori kemampuan 
siswa (tinggi sedang, rendah), selain meneliti secara kuantitatif, juga dikaji sikap siswa sebelum, selama, dan sesudah diberikan perlakuan melalui studi kualitatif menggunakan wawancara, observasi, dan angket skala sikap. Berikut ini Skema desain penelitian Mixed Method dengan Concurrent Embedded Model.

Analisis data hasil penelitian dilakukan untuk menjawab hal-hal berikut : peningkatan kemampuan representasi siswa yang memperoleh pembelajaran assesmen proyek dan siswa yang memperoleh pembelajaran konvensional, peningkatan kemampuan representasi siswa yang memperoleh assesmen proyek dapat berkurang kecemasanya dibandingkan dengan siswa yang memperoleh pembelajaran konvensional dilihat dari kemampuan awal matematika (tinggi, sedang dan rendah), hubungan antara kemampuan awal matematika (tinggi, sedang, rendah) dengan pembelajaran assesmen proyek terhadap kemampuan representasi, bagaimana implementasi assesmen proyek dalam pembelajaran matematika.

\section{HASIL PENELITIAN DAN PEMBAHASAN}

Data yang diolah dan dianalisis dalam penelitian ini meliputi skor pretes, skor postes, dan gain ternormalisasi kemampuan representasi matematis siswa. Berikut ini disajikan statistik deskriptif skor pretes, postes, dan gain ternormalisasi $(g$ ) pada tabel $1 \mathrm{di}$ bawah ini.

Tabel 1. Deskripsi Statistik Skor Kemampuan Representasi Matematis

\begin{tabular}{|c|c|c|c|c|c|c|c|c|c|c|c|}
\hline \multirow{2}{*}{ Tes } & \multicolumn{6}{|c|}{ Kelas Kontrol } & \multicolumn{5}{|c|}{ Kelas Eksperimen } \\
\hline & Skor & & & & $\bar{x}$ & & & & & & \\
\hline Pretes & & 5 & & 1 & 2,94 & ,91 & 5 & & 2 & 2,11 & 3,41 \\
\hline Postes & 0 & 5 & 9 & 0 & 6,69 & ,99 & 5 & 5 & 9 & 8,11 & 6,64 \\
\hline Gain & & 5 & ,36 & ,67 &, 50 &, 07 & 5 & ,48 &, 87 & ,68 & 0,1 \\
\hline
\end{tabular}

Tabel 1 di atas menunjukkan bahwa rataan pretes kelas kontrol 0,83 lebih tinggi daripada rataan pretes kelas eksperimen. Selanjutnya dilakukan uji statistik.

\section{Analisis Data Hasil Pretest}

\section{Uji Normalitas}

Berdasarkan hasil pengolahan data dengan SPSS 16 for windows diperoleh data sebagai berikut: 
Tabel 2 Tests of Normality

\begin{tabular}{lccccccc}
\hline & Kelas & \multicolumn{3}{c}{ Kolmogorov-Smirnov ${ }^{\mathrm{a}}$} & & \\
& & Statistic & $\mathrm{f}$ & Sig. & Statistic & $\mathrm{f}$ & Sig. \\
nilai_pretes & Eksperimen & .102 & 5 & $.200^{*}$ & .943 & 5 & .071 \\
& Control & .090 & 5 & $.200^{*}$ & .982 & 5 & .814 \\
\hline
\end{tabular}

Berdasarkan Tabel 2 terlihat bahwa nilai probalitas (sig.) untuk kelas eksperimen dan kontrol lebih besar dari 0,05 , ini berarti hipotesis nol $\left(\mathrm{H}_{0}\right)$ diterima. Dengan demikian sampel berasal dari populasi yang berdistribusi normal.

\section{Uji Homogenitas Varian}

Table 3 Test of Homogeneity of Variance

\begin{tabular}{llcccc}
\hline & Levene Statistic & df1 & df2 & \multicolumn{2}{c}{ Sig. } \\
\hline nilai_pretes & Based on Mean & .013 & 1 & 68 & .908 \\
Based on Median & .013 & 1 & 68 & .910 \\
Based on Median and & & & & .910 \\
with adjusted df & .013 & 1 & 67.910 & .906 \\
Based on trimmed mean & & & & 68
\end{tabular}

Pada Tabel 3 terlihat bahwa nilai probabilitas (sig.) lebih besar dari 0,05, ini berarti $\mathrm{H}_{0}$ diterima. Sehingga dapat disimpulkan bahwa data pretes kemampuan representasi matematis kelas eksperimen dan kontrol memiliki varians yang homogen.

\section{Analisis Data Postes Kemampuan Representasi Matematis Siswa}

Tabel 4. Kemampuan Representasi Matematis menggunakan Assesmen proyek

Kelas Skor Ideal Kemampuan Representasi Matematis

\begin{tabular}{lccccc}
\hline & & Minimum & Maksimum & Mean & $\begin{array}{c}\text { Standar } \\
\text { Deviasi }\end{array}$ \\
Eksperimen & 80 & 35 & 70 & 54,23 & 10,50 \\
Kontrol & 80 & 33 & 64 & 44,51 & 7,21 \\
\hline
\end{tabular}

Hasil penghitungan uji normalitas data postes kemampuan representasi matematis disajikan pada Tabel 5.

Tabel 5. Tests of Normality

\begin{tabular}{llcccccc}
\hline & Kelas & \multicolumn{3}{c}{ Kolmogorov-Smirnov $^{\mathrm{a}}$} & \multicolumn{3}{c}{ Shapiro-Wilk } \\
\hline \multirow{3}{*}{ nilai_prostes } & Statistic & Df & \multicolumn{1}{c}{ Sig. } & Statistic & Df & \multicolumn{1}{c}{ Sig. } \\
& Eksperimen & .103 & 35 & $.200^{*}$ & .968 & 35 & .386 \\
& Control & .136 & 35 & .101 & .940 & 35 & .054 \\
\hline
\end{tabular}


Berdasarkan Tabel 5 terlihat bahwa nilai probabilitas (sig.) untuk kelas eksperimen dan kelas kontrol lebih besar dari $\alpha=0,05$, ini berarti hipotesis nol $\left(\mathrm{H}_{0}\right)$ diterima. Artinya data kedua kelas eksperimen berasal dari populasi yang berdistribusi normal. Selanjutnya akan disajikan pada Tabel 6 mengenai uji homogenitas

Tabel 6. Test of Homogeneity of Variance

\begin{tabular}{llrrrrr}
\hline & & \multicolumn{2}{c}{ Levene } & & & \\
& & Statistic & df1 & df2 & \multicolumn{2}{c}{ Sig. } \\
\hline nilai_prostes & Based on Mean & .265 & 1 & 68 & .608 \\
& Based on Median & .312 & 1 & 68 & .578 \\
& $\begin{array}{l}\text { Based on Median and } \\
\text { with adjusted df }\end{array}$ & .312 & 1 & 66.348 & .578 \\
& Based on trimmed mean & .291 & 1 & 68 & .592 \\
\hline
\end{tabular}

Berdasarkan hasil perhitungan yang disajikan pada Tabel 6, nilai probabilitas (sig.) lebih besar dari 0,05, ini berarti hipotesis nol diterima. Sehingga dapat disimpulkan bahwa data bersifat homogen.

\section{Analisis Peningkatan Kemampuan Representasi Matematis Menggunakan Assesmen Proyek Berdasarkan Kemampuan Awal Matematika (KAM)}

Berikut ini disajikan sebaran sampel yang telah diambil untuk menentukan siswa mana yang termasuk tinggi, sedang dan rendah pada tabel 7 berikut ini:

Tabel 7. Sebaran siswa berdasarkan Kemampuan Awal Matematika (KAM)

\begin{tabular}{ccccc}
\hline & & \multicolumn{3}{c}{ Model Pembelajaran } \\
\hline \multirow{3}{*}{ KAM } & Eksperimen & Kontrol & Jumlah \\
\hline & Tinggi & 4 & 3 & 7 \\
& Sedang & 23 & 27 & 50 \\
& Rendah & 8 & 5 & 13 \\
& Jumlah & 35 & 35 & 70 \\
\hline
\end{tabular}


Tabel 8. Uji Normalitas gain Kemampuan Representasi Matematis

\begin{tabular}{llcrrrrrr}
\hline & Kelas & \multicolumn{3}{c}{ Kolmogorov-Smirnov $^{\mathrm{a}}$} & \multicolumn{3}{c}{ Shapiro-Wilk } \\
\hline \multirow{3}{*}{ N_gain } & & Statistic & Df & \multicolumn{1}{c}{ Sig. } & Statistic & df & \multicolumn{1}{c}{ Sig. } \\
& Eksperimen & .106 & 35 & $.200^{*}$ & .956 & 35 & .179 \\
& Control & .094 & 35 & $.200^{*}$ & .981 & 35 & .783
\end{tabular}

a. Lilliefors Significance Correction

*. This is a lower bound of the true significance.

Tabel 8, terlihat bahwa nilai probabilitas (sig.) untuk setiap pembelajaran lebih besar dari 0,05 , ini berarti bahwa $\mathrm{H}_{0}$ diterima. Dengan demikian, data skor gain kemampuan representasi matematis untuk setiap kelas pembelajaran berdistribusi normal.

Tabel 9. Test of Homogeneity of Variance

\begin{tabular}{|c|c|c|c|c|c|}
\hline & & $\begin{array}{l}\text { Levene } \\
\text { Statistic }\end{array}$ & df1 & df2 & Sig. \\
\hline \multirow[t]{4}{*}{ N_gain } & Based on Mean & 2.211 & 1 & 68 & .142 \\
\hline & Based on Median & 2.138 & 1 & 68 & .148 \\
\hline & $\begin{array}{l}\text { Based on Median and with } \\
\text { adjusted df }\end{array}$ & 2.138 & 1 & 54.957 & .149 \\
\hline & Based on trimmed mean & 2.185 & 1 & 68 & .144 \\
\hline
\end{tabular}

Pada tabel 9 terlihat bahwa nilai probabilitas (sig.) lebih besar dari 0,05, ini berarti hipotesis nol ( $\left.\mathrm{H}_{0}\right)$ diterima. Dengan demikian, varians populasi dari data gain kemampuan representasi matematis berdasarkan kelas pembelajaran datanya homogen.

\section{Perbandingan Peningkatan Kemampuan Representasi Berdasarkan Kelas Pembelajaran dan Kemampuan Awal Matematika (KAM)}

Tabel 10 Uji Normalitas Skor Kemampuan Representasi Matematis Berdasarkan Kelas Pembelajaran dan KAM

\begin{tabular}{llrrc}
\hline & Kelompok & \multicolumn{3}{c}{ Kolmogorov-Smirnov } \\
\hline \multirow{3}{*}{ Gain } & Statistic & df & \multicolumn{2}{c}{ Sig. } \\
& Eksperimen_Tinggi & .152 & 7 & $.200^{*}$ \\
& Eksperimen_Sedang & .115 & 20 & $.200^{*}$ \\
Eksperimen_Rendah & .265 & 9 & .068 \\
Kontrol_Tinggi & .245 & 6 & $.200^{*}$ \\
& Kontrol_Sedang & .118 & 18 & $.200^{*}$ \\
& Kontrol_Rendah & .244 & 10 & .095
\end{tabular}

Dari Tabel 10 terlihat bahwa nilai probablitas (sig.) untuk setiap kelas pembelajaran pada setiap kelompok KAM lebih besar dari 0,05, ini berarti hipotesis nol diterima. 
Dengan demikian, data skor gain kemampuan representasi matematis berdasarkan kelas pembelajaran dan kelompok KAM berdistribusi normal

Tabel 11. Levene's Test of Equality of Error Variances ${ }^{a}$

\begin{tabular}{lllllll}
\hline N_gain & & & & & & \\
\hline & $F$ & & df1 & & df2 & Sig. \\
& 1.388 & & 5 & & 64 & .241 \\
\end{tabular}

Pada Tabel 11 terlihat bahwa nilai probabilitas (sig.) lebih besar dari 0,05 , ini berarti hipotesis nol diterima. Artinya terdapat peningkatan kemampuan siswa.

Tabel 12. Tests of Between-Subjects Effects

\begin{tabular}{lrrrrr}
\hline Source & $\begin{array}{c}\text { Type III Sum } \\
\text { of Squares }\end{array}$ & df & Mean Square & \multicolumn{1}{c}{ F } & \multicolumn{1}{c}{ Sig. } \\
\hline Corrected Model & $.922^{\mathrm{a}}$ & 5 & .184 & 73.818 & .000 \\
Intercept & 13.109 & 1 & 13.109 & $5.250 \mathrm{E} 3$ & .000 \\
Kelas & .206 & 1 & .206 & 82.654 & .000 \\
Kam & .354 & 2 & .177 & 70.843 & .000 \\
Kelas * Kam & .046 & 2 & .023 & 9.261 & .000 \\
Error & .160 & 64 & .002 & & \\
Total & 25.342 & 70 & & & \\
Corrected Total & 1.081 & 69 & & &
\end{tabular}

a. $\mathrm{R}$ Squared $=.852$ (Adjusted R Squared $=.841$ )

Berdasarkan hasil pada tabel 12 diatas nilai probabilitas $($ sig. $=0,000)$ lebih kecil dari 0,05. Hal ini dapat disimpulkan bahwa antara siswa yang memperoleh pembelajaran yang menggunakan asesmen proyek dan konvensional terdapat perbedaan yang signifikan dalam pencapaian kemampuan representasi matematisnya.

Analisis Korelasi kecemasan matematika dengan kemampuan representasi

Tabel 13. Korelasi kecemasan dengan kemampuan representasi matematik dengan pembelajaran proyek

\begin{tabular}{llcr}
\hline & & Representasi & Kecemasan \\
\hline Representasi & Pearson & 1 & $.424^{*}$ \\
& Correlation & & .011 \\
& Sig. (2-tailed) & 35 & 35 \\
Kecemasan & $\mathrm{N}$ & $.424^{*}$ & 1 \\
& Pearson & .011 & \\
& Correlation & 35 & 35 \\
\hline & Sig. (2-tailed) & $\mathrm{N}$
\end{tabular}


Berdasarkan tabel di atas terlihat bahwa korelasi antara kecemasan matematika dengan kemampuan representasi yang menggunakan pembelajaran assesmen proyek menghasilkan angka 0,424. Maka dapat disimpulkan bahwa korelasi antara kecemasan matematika dengan kemampuan representasi matematis siswa yang menggunakan pembelajaran assesmen proyek adalah sedang.

Tabel 14. Korelasi Antara Kecemasan Matematika Dengan Kemampuan Representasi Matematika Menggunakan Pembelajaran Konvensional

\begin{tabular}{llrr}
\hline & & Representasi & Kecemasan \\
\hline Representasi & Pearson Correlation & 1 & .174 \\
& Sig. (2-tailed) & & .318 \\
& $\mathrm{~N}$ & 35 & 35 \\
Kecemasan & Pearson Correlation & .174 & 1 \\
& Sig. (2-tailed) & .318 & \\
& $\mathrm{~N}$ & 35 & 35 \\
\hline
\end{tabular}

Pada hasil analisis korelasi Pearson terlihat di Tabel 14 bahwa korelasi antara kecemasan matematika dengan menggunakan pembelajaran konvensional menghasilkan angka 0,174. Maka dapat disimpulkan bahwa korelasi antara kecemasan matematika dengan kemampuan berpikir kreatif matematis siswa yang menggunakan pembelajaran konvensional rendah. Dengan demikian, dapat disimpulkan bahwa tidak terdapat korelasi antara kecemasan matematika yang menggunakan pembelajaran konvensional.

Hasil penelitian ini, menghasilkan beberapa temuan mengenai kemampuan pemecahan masalah dan koneksi matematis yang dianalisis berdasarkan kelas pembelajaran dan Kemampuan Awal Matematika (KAM) yang dikelompokkan kedalam tiga kategori yaitu tinggi, sedang dan rendah. KAM diolah berdasarkan tiga ulangan terakhir dengan kriteria jika berada pada interval lebih dari 52,21 masuk ke kelompok tinggi, berada pada interval 30,07 $<x<52,21$ masuk ke kelompok sedang dan jika di bawah interval 30,07 dimasukan ke dalam kelompok rendah. Berikut ini pembahasan lengkapnya:

\section{Peningkatan Kemampuan Representasi Matematis Berdasarkan Kelas Pembelajaran dan KAM}

Hasil skor rata-rata pretes kemampuan representasi matematis yang didapat untuk kelas yang pembelajarannya menggunakan assesmen proyek adalah 14,33 sedangkan kelas yang pembelajarannya dengan konvensional 11,65. Hal ini menunjukan tidak terdapat 
perbedaan yang signifikan, artinya kedua kelas tersebut memiliki kemampuan awal representasi yang sama sebelum pembelajaran dilaksanakan.

Skor rata-rata postes kemampuan pemecahan masalah pada kelas yang menerapkan asesmen proyek didapat 0,65 . Sedangkan kelas yang pembelajarannya secara konvensional mendapat skor rata-rata postes adalah 0,51. Pengujian terhadap kedua rata-rata postes kemampuan representasi matematis siswa menunjukan terdapat perbedaan yang signifikan. Hal ini dapat dikatakan bahwa siswa pada kelas yang pembelajarannya menerapkan asesmen proyek memiliki kemampuan representasi yang yang lebih baik dibandingkan dengan siswa pada kelas pembelajaran konvensional.

Perbedaan kemampuan peningkatan representasi matematis tersebut juga didukung melalui rata-rata gain kemampuan representasi matematis pada kelas yang menerapkan asesmen proyek sebesar 0,65 dan gain kelas yang pembelajarannnya secara konvensional sebesar 0,51. Rata-rata gain tersebut mengindikasikan bahwa pada pembelajaran di kelas yang menerapkan asesmen proyek terjadi peningkatan kemampuan representasi matematis lebih tinggi dibandingkan peningkatan pada pembelajaran di kelas yang pembelajarannya secara konvensional. Hasil uji anova dua jalur terhadap uji peningkatan kemampuan representasi berdasarkan kemampuan awal matematika (KAM) diperoleh terdapat perbedaan yang signifikan peningkatan kemampuan representasi matematis siswa berdasarkan kelas pembelajaran dan kemampuan awal matematika (tinggi, sedang dan rendah). Interaksi antara kelas pembelajaran dan KAM tidak memberikan pengaruh yang signifikan terhadap peningkatan kemampuan representasi secara keseluruhan. Berdasarkan data-data tersebut dapat disimpulkan bahwa kemampuan representasi matematis siswa yang menerapkan assesmen proyek lebih baik dibandingkan dengan siswa yang menggunakan pembelajaran konvensional.

\section{Sikap Siswa Terhadap Pembelajaran yang Menerapan Assesmen Proyek}

Berdasarkan hasil yang didapat, bahwa sikap siswa terhadap mata pelajaran matematika dengan skor rata-rata 3,92. Sikap siswa terhadap pembelajaran yang menggunakan asesmen proyek berbasis masalah dengan skor rata-rata 3,48. Hasil tersebut memberikan gambaran bahwa pembelajaran yang menggunakan asesmen proyek mampu membantu siswa untuk mengerjakan soal matematika. Hal ini dikarenakan pada pembelajaran yang menerapkan asesmen proyek siswa terbantu pemahamannya, sehingga mereka ada keinginan untuk mengerjakan tugas matematika. 


\section{Penerapan Assesmen Proyek}

Berdasarkan analisis pembelajaran yang menerapkan asesmen proyek memungkinkan setiap siswa mengenali sendiri materi yang sedang dipahami melalui diskusi di dalam kelompoknya masing-masing. Hal ini sesuai dengan pendapat Dewey (Trianto, 2009:91) "belajar berdasarkan masalah adalah interaksi antara stimulus dengan respon, merupakan hubungan antara dua arah belajar dan lingkungan. Dalam pembelajaran yang menggunakan asesmen proyek, yang di awal pembelajarannya memunculkan proyek untuk membuat siswa lebih tertarik belajar matematika. Pada proses pemecahan masalah guru memberikan sedikit bantuan kepada siswa agar dapat menyelesaikan masalah tersebut, bantuan seperti ini dikenal dengan scafolding, artinya bahwa guru berperan sebagai fasilitator agar siswa mampu menjawab permasalahan tugas proyek ataupun permasalahan yang disediakan dalam bahan ajar dengan baik.

Berbeda dengan pembelajaran konvensional dimana siswa, tidak diberikan masalah, guru langsung melaksanakan pembelajaran. Hal ini sesuai dengan pendapat Brooks \& Brooks (Fakhrudin, 2011:36) mengemukakan pembelajaran konvensional mengikuti pola sebagai berikut: (a) guru sering mencontohkan pada siswa bagaimana menyelesaikan soal, (b) siswa belajar dengan cara mendengar dan menonton guru melakukan matematika, kemudian mencoba memecahkannya sendiri (c) pada saat mengajar matematika, guru langsung menjelaskan topik yang akan dipelajari, dilanjutkan dengan pemberian contoh dan soal untuk latihan.

Kendala yang lain adalah masalah perijinan untuk mengerjakan tugas proyek, seperti mencari bahan-bahan di internet, mencari benda-benda yang termasuk dalam tugas karena sekolah yang menjadi penelitian ini sekolah yang berbasis pondok pesantren, yang segala sesuatu berhubungan dengan siswa yang keluar dari lingkungan sekolah untuk mencari bahan tugas proyek harus mendapatkan ijin dari pengurus pondok pesantren. Ini disiasati dengan peneliti memberi tahukan kepada pengurus pondok secara langsung kalau ada tugas dari sekolah untuk mencari bahan untuk pengerjaan tugas proyek. Kebingungan siswa juga nampak ketika guru melakukan pretes di awal pembelajaran, bahkan ada yang berkata "pak belum diajari kok sudah ulangan? Ntr nilai saya jelek pak", peneliti memahami karena siswa terbiasa dengan pembelajaran konvensional yang dilakukan oleh guru sehingga ketika menerima pretes di awal pembelajaran mereka merasa kebingungan, namun peneliti memberikan penjelasan kepada siswa bahwa pretes dilakukan sebagai bahan pijakan untuk menentukan peningkatan hasil belajar. 
Temuan lain yaitu pada saat siswa melakukan presentasi tugas matematika, adanya keinginan bertanya sudah ada pada siswa, namun mereka masih takut untuk melakukannya sehingga pertanyaan kadang ditanyakan pada guru secara langsung. Namun peneliti langsung memberikan pemahaman bahwa bertanya langsung kepada kelompok yang sedang melakukan presentasi di depan itu lebih bermakna dan jika ada yang kurang dalam menjelaskan materi yang disampaikan oleh teman maka guru yang akan meluruskannya.

\section{Kecemasan Matematika}

Menurut Nawangsari (2001) mengungkapkan bahwa salah satu faktor yang dapat mempengaruhi tingkat kecemasan dalam menghadapi mata pelajaran matematika adalah materi yang dianggap sulit serta cara mengajar yang sulit dipahami. Oleh karena itu diperlukan suatu cara mengajar yang membuat rasa nyaman siswa sehingga materi yang disampaikan dapat lebih mudah dimengerti oleh siswa. Apabila siswa beranggapan bahwa materi tersebut mudah maka tingkat kecemasan dalam menghadapi mata pelajaran matematika akan berkurang. Hal ini senada dengan pendapat Freud dari Ahli Psikoanalisis, Calvin S. Hall dari Ahli Kultural dan Mowrer dari Ahli Teori Belajar (dalam Soeharjono, 1988) yang menyatakan bahwa faktor yang mempengaruhi kecemasan adalah keadaan lingkungan di mana keadaan itu dapat dilihat pada lingkungan sekolah terutama di dalam kelas.

Townsend (1996) memberikan gambaran tentang tingkat kecemasan, mulai dari kecemasan dalam kategori ringan sampai dengan kecemasan berat. Menurutnya, kecemasan ringan dapat memberi motivasi, dapat menghasilkan pertumbuhan dan kreativitas. Sedangkan kecemasan pada kategori sedang merupakan sebuah manifestasi yang terjadi karena meningkatnya kelelahan, lahan persepsi siswa menyempit akibatnya muncul ketegangan, siswa mampu untuk belajar tetapi tidak optimal, konsentrasi menurun, mudah tersinggung, tidak sabar, sulit untuk mengingat, marah dan menarik diri dari lingkunngan. Kecemasan berat hilangnya lahan persepsi, seseorang tidak lagi dapat berfikir tentang orang lain, manifestasi yang muncul berfokus pada diri sendiri, tidak mau belajar secara efektif. Berdasarkan observasi dan wawancara yang dilakukan selama penelitian didapatkan informasi bahwa sebagian besar siswa beranggapan pelajaran matematika adalah pelajaran yang sulit, rumit dan menakutkan sehingga tingkat kecemasan siswa tinggi.

\section{Korelasi Kecemasan Matematika dengan Representasi matematika}

Menurut Foong (Keow, 2012) dari hasil penelitiannya bahwa baik kecemasan belajar matematika maupun kecemasan tes matematika berkorelasi negatif dengan prestasi 
belajar matematika. Sedangkan yang lebih berkaitan dengan kreativitas, Haylock (Fetterly, 2010) mengemukakan bahwa kreativitas matematika yang tinggi pada siswa akan membuat siswa mempunyai kecemasan matematika yang rendah. Berdasarkan hasil analisis pada siswa yang menggunakan pembelajaran Assesmen proyek dapat meningkatkan representasi didapatkan bahwa terdapat korelasi antara kecemasan matematika dengan kemampuan representasi.

Sedangkan untuk hasil analisis korelasi yang pembelajarannya menggunakan model konvensional didapatkan bahwa tidak terdapat korelasi yang erat antara kecemasan matematika dengan kemampuan bepikir kreatif matematis siswa. Hal ini tidak sesuai dengan pendapat diatas yang menyatakan terdapat korelasi negatif antara kecemasan dengan kemampuan berpikir kreatif matematis siswa. Dari hasil wawancara didapatkan keterangan bahwa siswa merasa senang dan lebih tertarik dalam belajar matematika dengan menggunakan pembelajaran assesmen proyek walaupun pada awalnya siswa merasa bingung dan belum terbiasa, tapi seiring berjalannya waktu, siswa dapat beradaptasi dengan pembelajaran seperti ini.

\section{KESIMPULAN}

Berdasarkan hasil temuan dan pembahasan mengenai representasi untuk mengurangi kecemasan matematis siswa melalui penerapan pemebelajaran yang menggunakan asesmen berbasis proyek siswa yang pembelajarannya menggunakan pembelajaran konvensional, diperoleh beberapa kesimpulan sebagai berikut:

1) Terdapat perbedaan peningkatan kemampuan representasi matematis siswa yang memperoleh assesmen berbasis proyek dan siswa yang memperoleh pembelajaran konvensional.

2) Peningkatan kemampuan representasi matematis siswa yang memperoleh assesmen berbasis proyek lebih baik daripada siswa yang memperoleh pembelajaran konvensional dilihat dari kemampuan awal matematika (tinggi, sedang dan rendah).

3) Terdapat hubungan antara pembelajaran assesmem proyek dengan kemampuan Representasi matematis siswa pada kelas eksperimen, sedangkan untuk siswa yang menggunakan pembelajaran konvensional tidak terdapat hubungan.

4) Terdapat hubungan antara kemampuan representasi dengan kecemasan.

5) Sikap siswa positif setelah menggunakan assesmen berbasis proyek untuk mengurangi kecemasan terhadap pembeljaran matematika. 


\section{DAFTAR PUSTAKA}

Aisyah, S. (2012). Meningkatkan Kemampuan Representasi dan Pemecahan Masalah Matematis Melalui Matematical Modelling dalam Model Problem Based Learning. Tesis UPI : tidak diterbitkan.

Anita.I.W (2011). Pengaruh Kecemasan Matematika Terhadap Kemampuan Pemecahan Masalah dan Koneksi Matematika Siswa SMP. Tesis UPI : tidak diterbitkan

Auliya.R.N. (2013). Pengaruh Model Pembelajaran Cooperative Tipe CRH (Course, Review, Hurras) Terhadap Kemampuan Pemahaman dan Kecemasan Matematika SMP. Tesis UPI Bandung: tidak diterbitkan

Ahmad, A dan Widodo. S (2003). Psikologi Belajar. Jakarta: Rineka Cipta.

Arikunto, S. (2012). Dasar-dasar Evaluasi Pendidikan. Jakarta: Bumi Aksara.

Bilik.W.I. (2012). Pengaruh Implementasi Assesmen otentik terhadap Prestasi Belajar Matematika dan Motivasi Berprestasi. Karya Ilmiah, dipublikasikan pasca.undikasha.ac.aid

Departemen Kurikulum Tingkat Satuan Pendidik (KTSP).2006. Tujuan Pendidikan Matematika. Badan Standar Nasional Pendidikan (BSNP)

Hartanti \& Judith E.D. (1997). Hubungan antara konsep diri dan kecemasan menghadapi masa depan dengan penyesuaian sosial anak-anak Madura. Jurnal Psikologi Pendidikan: Anima. 12, 46, 2007.

Hudoyo, H. (2002). Representasi Belajar Berbasis Masalah. Journal Matematika atau Pembelajaranya. ISSN; 085-7792 tahun terbit VIII. Edisi Khusus.

Ismunandar, D. (2016). Pembelajaran Bermuatan Disposisi Matematika Pada Kelas X Program IPS. Mathline. Vol. 1, No 2, Hal 70-82.

Karyono. (2014). Penerapan Assesmen Portopolio berbasis masalah untuk Meningkatkan Kemampuan Pemecahan dan Koneksi Matematis siswa SMP. Tesis pada FPS Unpas: Tidak diterbitkan

Kemendikbud. (2013). Konsep Pendekatan Scientifik Diklat Guru dalam rangka Implementasi Kurikulum 2013, diterbitkan oleh: Kementrian Pendidikan dan Kebudayaan

Kunandar. (2013). Penilaian Autentik (Penilaian Hasil Belajar Peserta Didik Berdasarkan Kurikulum 2013).Jakarta : Raja Grafindo Persada

Mulyasa, E. (2013) Pengembangan dan Implementasi Kurikulum 2013. Bandung: Remaja Rosada Karya.

Majid, a. (2012). Perencanaan Pembelajaran Berdasarkan Kompetensi Guru. Bandung: Remaja Rosda Karya. 
Masriyah. (2010). Implementasi KTSP Pada Assesmen Autentik dalam Pembelajaran Matematika.

Nawangsari, N. A. F. (2001). Pengaruh self-efficacy dan expectancy-value terhadap kecemasan menghadapi pelajaran matematika. Jurnal Psikologi Pendidikan: $\underline{\text { Insan }}$ media psikologi, 3,2, 2001,

(2000). Kecemasan siswa pada bidang matematika di SLTP Surabaya (Laporan penelitian universitas airlangga).Surabaya : Universitas Airlangga.

National Council Teacher Mathematics (2000). Principle and Standards for School Mathematic. Virginia : NCTM.

Risnawati. (2012). Pengaruh Pembelajaran Dengan Pendekatan Induktif-Deduktif Berbantuan Program Cabri Geometri Terhadap Peningkatan Kemampuan Representasi Matematika Siswa Sekolah Menengah Pertama. Tesis UPI : tidak diterbitkan.

Ruseffendi, E.T. (2006). Pengantar Kepada Membantu Guru Mengembangkan Kompetensiya Dalam Pelajaran Matematika untuk Meningkatkan CBSA. Bandung: Tarsito

(2005). Pengajaran Matematika- CBSA. Bandung : Tarsito.

Sa'dijah, C. (2009). Assesmen Kinerja dalam Pembelajaran Matematika. Journal Pendidikan Inovatif, Jilid 4 No.2 Maret 2009.

Stuart, V. (2007). Math Curs or Math Anxiety Teaching children matematika, 6.30-340.

Sugiyono. (2012). Metode Penelitian Kombinasi (MIX METHODS). Bandung : Alfabeta. (2010).Metode Penelitian Kuantitatif, Kualitatif dan R \&D.

Bandung: Alfabeta.

Soehardjono, L \& Endang W.G. (1988).Kecemasan pada anak dan remaja. Majalah anima : Media Psikologi Indonesia.

Uno, H.B (2012), Teori Inovasi dan Pengukurannya. Gorontalo : Bumi Aksara

Wahyudin. (2013). Matematika Dasar Pengetahuan Bermuatan Pedagogis. Bandung: Mandiri.

Wahyuni. S. (2012). Peningkatan Kemampuan Representasi Matematika dan Self Esteen Siswa Sekolah Menengah Pertama dengan Menggunakan Model Pembelajaran ARIAS. Tesis UPI Bandung: tidak diterbitkan

Widiastuti. (2010). Pengaruh Pembelajaran Model Activities (MEAs) Terhadap Kemampuan Representasi Matematis dan Self Efficaci Siswa. Tesis UPI : tidak diterbitkan. 